\title{
Pengalaman Flow dalam Belajar
}

\author{
Lucky Purwantini ${ }^{1}$ \\ Program Studi Psikologi Universitas Islam “45” Bekasi \\ purwantini.lucky@gmail.com
}

\begin{abstract}
Flow is a condition when individual merges within his/her activity. When a person in flow state, he/she can develop his/her abilities and more succes in learning. The purpose of the study is to understand flow experience in learning among undergaduate student. The study used case study qualitative approach. Informan of this research was an undergraduate student which had flow experience. Data was collected by an interview. According to the result, subject did not experienced flow in learning process, as likes he was in meditation. It happened because when he learned something, he felt be pressed by tasks. It's important for individu to relax when they are learning.

Key words: flow experience, learning, undergraduate student
\end{abstract}

\begin{abstract}
Abstrak. Flow adalah kondisi yang dialami individu ketika individu tersebut menyatu dengan kegiatan yang dilakukannya. Ketika seseorang berada dalam kondisi flow, ia dapat mengembangkan kemampuannya dan lebih berhasil dalam belajar. Tujuan penelitian ini adalah untuk memahami pengalaman flow dalam belajar pada seorang mahasiswa pascasarjana. Penelitian ini menggunakan desain kualitatif dengan pendekatan studi kasus. Subjek adalah seorang mahasiswa laki-laki pascasarjana yang pernah mengalami flow. Data dikumpulkan dengan wawancara. Hasil penelitian menunjukkan bahwa subjek tidak mengalami flow dalam belajar, sebagaimana yang ia alami dalam meditasi. Hal itu terjadi karena saat belajar ia merasa tertekan oleh tugas. Penting bagi individu untuk merasa tenang pada saat belajar.
\end{abstract}

Kata kunci: pengalaman flow, pembelajaran, mahasiswa pascasarjana

Flow merupakan suatu keadaan dimana individu mengalami peleburan total dalam kegiatan yang dilakukannya. Hal tersebut dicapai melalui intensitas dan perhatian terfokus pada kegiatan tersebut. Keadaan flow dapat memotivasi individu dan komunitas (Schouten, McAlexander, \& Koenig, 2007) untuk meraih keunggulan. Ketika mengalami flow, muncul keinginan dalam diri mereka untuk mengalaminya kembali dan untuk itu, mereka akan mencari tugas-tugas lain yang lebih menantang
(Engeser \& Rheinberg, 2008), dan hal itu berpengaruh pada kesejahteraan psikologis mereka (Schouten, McAlexander, \& Koenig, 2007). Selain itu, flow juga berhubungan dengan hasil pembelajaran yang positif (Scoresby \& Shelton, 2010).

Ketika seseorang berada dalam kondisi flow, ia sering mengalami kehilangan waktu, kehilangan kesadaran diri dan lingkungan, dan peningkatan pada kemampuannya (Scoresby \& Shelton, 2010). Selain itu, ia juga merasakan efisiensi kognisinya 
secara berturut-turut, termotivasi dan bahagia (Csikzentmihalyi dalam Esenger \& Rheinberg, 2008). Dalam melakukan kegiatannya, ia menjadi "in the zone", melebur dan menjadi satu dengan apa yang dilakukannya secara total, merasa seperti "segala sesuatu sudah oke", dan benar-benar terfokus pada kegiatannya (Martin \& Jackson, 2008).

Ketika ia terganggu perhatiannya atau terdistraksi oleh suatu hal, ia tidak lagi berada dalam kondisi flow (Scoresby \& Shelton, 2010). Distraksi yang dialami individu ketika ia berada dalam kondisi flow dapat mengganggu keberadaannya dalam flow, dan untuk kembali ke dalam kondisi flow, individu tersebut memerlukan beberapa waktu (Csikzentmihalyi, 1996). Distraksi tersebut dapat berupa kebisingan (Scoresby \& Shelton, 2010), teralihnya fokus dan konsentrasi pada hal lain (Csikzentmihalyi, 1996), dan lain sebagainya.

Flow terjadi ketika kesulitan dan tantangan yang dihadapi individu dalam suatu tugas seimbang dengan kemampuan yang dimilikinya (Esenger \& Rheinberg, 2008). Jika kemampuan yang dimilikinya melebihi tingkat kesulitan atau tantangan yang dihadapi, ia akan merasa relaks atau bosan, tetapi jika tingkat kesulitan dan tantangan yang dihadapi melebihi kemampuan yang dimilikinya, ia akan merasa sangat bersemangat atau cemas (Baumann dan Scheffer, 2010).

Menjadi autotelik merupakan pengalaman penting dalam flow (Csikzentmihalyi, 2008). Autotelik merujuk pada motivasi intrinsik individu dalam melakukan suatu aktivitas yang mendatangkan flow, dalam hal ini, tujuan individu melakukan aktivitas itu adalah untuk merasakan "luapan kegembiraan" yang timbul dari aktivitas itu, bukan untuk tujuan lain yang menguntungkan dari aktivitas itu. Sebagai contoh, misalnya untuk mendapatkan uang atau status, jika hal itu yang menjadi motivasinya maka pengalaman itu disebut exotelic. Individu yang autotelik rela mengeluarkan banyak uang, waktu, dan perhatian mereka untuk aktivitas itu hanya untuk merasakan flow. Csikzentmihalyi (1996) menyatakan bahwa saat suatu aktivitas menjadi autotelik, tidak ada alasan lain untuk melakukan aktivitas itu selain untuk merasakan "sensasi rasa/flow" yang ditimbulkan aktivitas itu.

Penelitian tentang flow diawali oleh Csikzentmihalyi (Esenger \& Rheinberg, 2008) dengan melakukan wawancara dengan banyak orang, seperti seniman, atlit, dan ilmuwan (Csikzentmihalyi, 1997), tentang alasan mereka melakukan suatu aktivitas dengan komitmen tinggi tanpa ada ganjaran eksternal yang jelas. Ia menemukan bahwa beberapa aktivitas memberikan suatu "sensasi rasa" yang ia sebut sebagai "flow state" atau "pengalaman flow" (Esenger \& Rheinberg, 2008). Seiring berjalannya waktu, banyak peneliti yang telah melakukan penelitian tentang flow dalam berbagai bidang, di antaranya dalam bidang olahraga, pekerjaan, dan pendidikan (Martin \& Jackson, 2008).

Dalam dunia pendidikan, pengalaman flow tersebut dapat 
berlangsung ketika individu sedang belajar. Belajar merupakan kegiatan alami yang dilakukan manusia sejak ia dilahirkan. Sejak kecil, manusia menggunakan kelima inderanya untuk belajar, dimulai dari mengamati kedua orang tua. Dari pengamatan tersebut, manusia belajar menirukan. Inilah awal fase proses belajar pada manusia. Seiring waktu, dengan semakin bertambahnya usia seseorang, ia tak hanya belajar dengan menirukan. Perubahan tingkah lakunya adalah hasil dari latihan, pengalaman, dan interaksinya dengan lingkungan.

Proses belajar diawali dengan memberikan perhatian pada suatu hal. Informasi yang didapat dari panca indera, akan masuk ke dalam ingatan jangka pendek. Bila informasi tersebut dianggap penting, informasi tersebut akan berjalan ke ingatan jangka panjang. Bila dibutuhkan, informasi yang berada dalam ingatan jangka panjang dapat dikeluarkan. Dalam perjalanannya, individu terkadang mengalami lupa. Menurut Surya (dalam Kertamuda, 2006), lupa merupakan suatu keadaan dimana individu kehilangan kemampuan untuk mengeluarkan kembali informasi yang telah tersimpan baik dalam ingatan jangka panjang maupun ingatan jangka pendek.

Proses belajar tersebut selalu terjadi baik ketika individu duduk di bangku sekolah dasar maupun saat individu menjadi mahasiswa. Mahasiswa merupakan orang yang terdaftar di suatu perguruan tinggi dan belajar di sana. Rentang usia mahasiswa beragam. Ada yang cenderung homogen, ada pula yang heterogen, dalam arti bervariasi. Mahasiswa jenis ini biasanya terdapat pada jenjang magister dimana penyebaran usia mereka tidak merata. Ada yang masih berada dalam fase dewasa awal, ada pula yang menginjak fase dewasa tengah maupun akhir. Mahasiswa jenjang magister tidak seperti mahasiswa jenjang sarjana yang hampir serentak melanjutkan kuliah setelah lulus dari sekolah menengah atas. Mahasiswa jenjang magister ada yang sudah bekerja, menikah dan memiliki anak, walau ada pula yang langsung melanjutkan kuliah setelah lulus menjadi sarjana. Dalam penelitian ini, peneliti mengkhususkan diri pada mahasiswa jenjang magister yang langsung melanjutkan kuliah setelah lulus dari jenjang sarjana.

Mahasiswa jenjang magister yang langsung melanjutkan kuliah setelah lulus dari jenjang sarjana berada pada tahap perkembangan dewasa awal. Masa dewasa awal adalah sebuah masa yang ditandai dengan kondisi fisik (meliputi daya tahan dan taraf kesehatan) yang prima. Dari sisi kognisi, menurut Piaget (dalam Papalia, Olds, \& Feldman, 2005), masa dewasa awal memasuki tahap berpikir abstrak yang lebih tinggi yang dikenal dengan berpikir postformal. Berpikir postformal merupakan jenis berpikir yang telah matang yang berdasar pada pengalaman subjektif dan intuisi seperti halnya berpikir logis, yang berguna ketika menghadapi ambiguitas, ketidakpastian, ketidakkonsistenan, kontradiksi, ketidaksempurnaan, dan hal-hal yang mencurigakan. Penelitian 
ini bertujuan untuk memahami pengalaman flow dalam belajar pada mahasiswa. Pertanyaan ini akan menjelaskan tentang gambaran pengalaman flow yang dialami mahasiswa pada jenjang magister tersebut.

Adalah Mihaly Csikzentmihalyi (1996) yang memperkenalkan konsep flow. Ia membangun sebuah teori tentang pengalaman optimal yang berdasar pada konsep flow, yaitu suatu keadaan dimana seseorang melebur dalam suatu kegiatan yang ia senangi, dan pengalaman tersebut menimbulkan suatu kesenangan tersendiri yang membuat orang itu akan melakukannya lagi sekalipun hal itu memakan biaya, hanya untuk mengalami "sensasi rasa" yang timbul ketika melakukan kegiatan tersebut (Csikzentmihalyi, 2008).

Pengalaman optimal merupakan suatu keadaan ketika seseorang berada pada konsentrasi tinggi, mengalami keterlibatan pada suatu hal, pengendalian situasi, memiliki tujuan dan mendapat umpan balik yang jelas, merasakan kepuasan, dan termotivasi secara intrinsik (Csikszentmihalyi \& Csikszentmihalyi dalam Bassi, dkk., 2006). Motivasi intrinsik merupakan ketertarikan dan kesenangan individu pada suatu hal yang tertampilkan melalui perilaku (Deci \& Ryan, 1985; Vallerand \& Ratelle, 2002, dalam Waterman, 2005). Ketika individu mengalami pengalaman optimal, ia merasakan kegembiraan, sebuah rasa senang yang dalam dan berlangsung lama, serta hal itu menjadi peristiwa yang terpaku dalam ingatan tentang bagaimana seharusnya hidup itu berjalan (Csikzentmihalyi, 2008).

Csikzentmihalyi mengawali penelitiannya tentang flow dengan mewawancarai beberapa orang tentang alasan mereka berkomitmen tinggi ketika melakukan sesuatu tanpa ada ganjaran eksternal yang jelas. Dari penelitiannya tersebut, ia menemukan bahwa beberapa kegiatan memberikan suatu sensasi yang ia sebut sebagai "flow state" atau "pengalaman flow" (Esenger \& Rheinberg, 2008). Setiap aktivitas yang menimbulkan flow memberikan suatu rasa penemuan baru, suatu perasaan kreatif yang membawa seseorang pada suatu kenyataan baru. Hal itu mendorong individu ke tingkat pencapaian yang lebih tinggi (Csikzentmihalyi, 2008).

Csikzentmihalyi menyatakan bahwa semakin sering individu mengalami flow, semakin sering individu itu bahagia. Namun, kebahagiaan itu tidak diperoleh ketika individu itu sedang mengalami flow, melainkan ketika ia telah usai dari periode flow tersebut. Dikatakan olehnya bahwa kebahagiaan merupakan distraksi saat flow. Hubungan antara flow dan kebahagiaan bergantung pada seberapa kompleks kegiatan yang menimbulkan flow dan apakah hal itu mengarahkan individu pada tantangan baru.

Terdapat sembilan komponen flow menurut Csikzentmihalyi (1996) : 1) memiliki tujuan yang jelas. Individu yang berada dalm kondisi flow selalu mengetahui apa yang yang harus dikerjakannya, dan mereka menikmati pekerjaan itu. 2). Adanya umpan balik 
dengan segera dari apa yang dilakukan. Umpan balik yang diperoleh biasanya berupa emosi yang positif seperti kepuasan, kenikmatan, kesenangan dan lain sebagainya, dan emosi tersebut berlangsung selama kondisi flow.3) Adanya keseimbangan antara kemampuan yang dimiliki dengan tingkat kesulitan dan tantangan yang dihadapi.

Aktivitas yang dilakukan untuk mendapatkan kondisi flow harus seimbang antara kemampuan dengan kesulitan dan tantangannya, tidak terlalu mudah atau tidak terlalu sulit. Baumann dan Scheffer (2010) menjelaskan bahwa jika kemampuan yang dimiliki individu melebihi tingkat kesulitan, ia akan merasa relaks atau kebosanan, tetapi jika tingkat kesulitan melebihi kemampuan yang dimilikinya, ia akan merasakan sangat bersemangat untuk melakukan kegiatan itu atau ia merasakan kecemasan.

Untuk mencapai kondisi flow, individu membutuhkan fokus yang terarah serta konsentrasi penuh terhadap apa yang dikerjakan dengan batasan-batasan yang jelas. Mereka yang mengalami flow memberikan pikiran, kesadaran dirinya, dan terfokus pada kegiatan yang sedang dilakukannya saat itu juga. Mereka tidak memikirkan hal-hal lain di luar kegiatan itu dan tidak mengalami kekhawatiran akan kegagalan karena ketika mereka mengkhawatirkan kegagalan, mereka tidak akan dapat berkonsentrasi total disebabkan perhatiannya akan terbagi antara apa yang dilakukan dan perasaan untuk mengendalikan kegagalan itu.
Dalam kondisi flow, kesadaran individu seolah-olah "menghilang" dan dirinya masuk ke dalam suatu dunia yang diciptakan oleh kegiatan yang tengah dilakukannya tersebut. Selain itu, waktu seolah terdistorsi. Ketika berada dalam kondisi flow, individu melupakan waktu. Jam yang terlewati berjalan seperti menit. Seberapa banyak waktu yang yang terlewati tergantung pada apa yang individu lakukan.

Dalam kondisi flow, kegiatan yang dilakukan individu berubah menjadi autotelik. Autotelik berarti ketika individu melakukan suatu kegiatan, ia melakukan itu bukan karena mengharapkan beberapa keuntungan, melainkan karena "sensasi rasa" yang ditimbulkan kegiatan itulah yang membuatnya menjadi istimewa. Ketika mengalami autotelik, individu memberikan perhatiannya demi kegiatan itu sendiri (Csikzentmihalyi, 2008). Tidak ada alasan lain untuk melakukan kegiatan itu kecuali untuk merasakan pengalaman yang mereka berikan (Csikzentmihalyi, 1996).

Csikzentmihalyi (Egbert, 2003) menyatakan bahwa flow memberikan kontribusi pada performa yang optimal dan belajar. Ketika individu mengalami flow dalam belajar, ia akan memusatkan perhatiannya pada apa yang dipelajarinya. Karena menikmati kegiatan belajar, siswa tersebut akan lebih sulit terserang stres dan sebagai akibatnya ia akan merasa bahagia. Kebahagiaan yang dirasakannya saat belajar dapat membuat prestasinya meningkat.

Namun ketika sedang berada dalam kondisi flow, individu terkadang 
mengalami distraksi yang dapat mengganggu kondisi flow, dan perlu beberapa waktu untuk membuat diri kembali berada dalam kondisi flow. Semakin seseorang ambisius dalam menyelesaikan tugas, semakin mudah ia mengalami distraksi (Csikzentmihalyi, 1996). Teralihnya fokus dan konsentrasi pada hal lain ketika berada dalam kondisi flow dapat menyebabkan distraksi yang akhirnya dapat mengakhiri proses kreatif yang terjadi.

\section{Belajar}

Chaplin (2002) mendefinisikan belajar sebagai perubahan yang relatif permanen dalam hal tingkah laku sebagai hasil dari pengalaman. Kertamuda (2006) mendefinisikan belajar sebagai suatu proses keseluruhan tingkah laku manusia yang sifatnya relatif menetap sebagai hasil dari latihan, pengalaman, dan interaksi manusia dengan lingkungannya. Kimble (dalam Hergenhahn \& Olson, 2009) mengartikan belajar sebagai perubahan yang relatif permanen dalam potensi perilaku yang terjadi akibat praktek yang diperkuat.

Dari definisi-definisi tersebut, dapat disimpulkan bahwa belajar merupakan perubahan perilaku yang dialami individu sebagai akibat dari pengalaman individu itu sendiri maupun lingkungan sekitarnya.

Menurut Kertamuda (2006), terdapat tiga faktor yang dapat mempengaruhi belajar, yaitu pertama,faktor internal merupakan faktor yang berasal dari dalam diri individu, termasuk di dalamnya aspek fisiologis, meliputi kondisi fisik, dan faktor psikologis, yang meliputi tingkat intelligensi, motivasi, bakat, minat, dan sikap. Kedua, faktor eksternal merupakan faktor yang berasal dari luar diri individu, meliputi lingkungan non sosial seperti keadaan cuaca dan tempat, dan faktor sosial seperti faktor manusia atau sesama manusia baik secara langsung maupun tidak langsung. Ketiga, faktor pendekatan belajar, yaitu strategi yang digunakan dalam menunjang efektivitas dan efisiensi proses pembelajaran tertentu, termasuk di dalamnya efisiensi usaha belajar, yakni usaha yang digunakan untuk mendapatkan hasil belajar yang memuaskan seperti penggunaan tenaga, pikiran, dan waktu, dan efisiensi hasil belajar, yaitu usaha belajar tertentu yang memberikan prestasi belajar tinggi.

Dalam belajar, terkadang individu mengalami apa yang disebut sebagai lupa. Surya (dalam Kertamuda, 2006) mendefinisikan lupa sebagai suatu keadaan dimana individu kehilangan kemampuan untuk mengeluarkan kembali informasi yang telah tersimpan baik dalam ingatan jangka panjang maupun ingatan jangka pendek. Beberapa hal yang menyebabkan lupa diantaranya adalah karena adanya tekanan secara otomatis pada informasi yang telah ada oleh informasi baru dan terjadi keusangan informasi, dalam hal ini informasi menghilang karena tidak pernah digunakan.

Kejenuhan juga terkadang dialami individu dalam belajar. Kejenuhan terjadi karena proses belajar telah sampai pada batas kemampuan jasmaniah karena individu mengalami 
kebosanan dan keletihan.

\section{Metode}

Penelitian ini menggunakan desain penelitian kualitatif dengan pendekatan studi kasus. Subjek dalam penelitian seorang mahasiswa jenjang magister yang langsung melanjutkan studi kemagisteran setelah lulus dari jenjang sarjana, yang berdasarkan usianya masuk ke dalam tahap perkembangan dewasa awal, dan pernah mengalami flow. Data dalam penelitian ini dikumpulkan melalui wawancara mendalam. Untuk menganalisis data yang didapat, digunakan teknik analisis data model interaktif dari Miles dan Huberman (1994). Analisis model ini terdiri dari reduksi data, penyajian data (display data), dan kesimpulan/verifikasi (Miles \& Huberman, 1994).

\section{Hasil}

Berdasarkan wawancara yang dilakukan, diketahui bahwa subjek pernah mengalami kondisi flow. Kondisi flow dialami subjek dalam meditasi. Menurut subjek, meditasi adalah salah satu cara untuk menghalau pikiranpikiran negatif. Subjek mengatakan bahwa pikiran kita sering tidak fokus dan bercabang kemana-mana. Meditasi dilakukan untuk menghalau pikiranpikiran negatif yang timbul agar pikiran kita tenang.

Flow ketika meditasi dirasakan subjek ketika tubuhnya berada dalam kondisi yang prima. Menurut subjek, flow memerlukan banyak faktor pendukung, diantaranya tubuh berada dalam kondisi prima, gelombang otak berada pada gelombang alpha, JURNAL ILMU PERILAKU konsentrasi, dan tidak ada distraksi. Jika salah satu faktor tersebut tidak mendukung, meditator tidak akan dapat mencapai kondisi flow. Subjek membedakan meditasi biasa dengan meditasi flow. Menurutnya, meditasi biasa adalah meditasi yang bertujuan untuk rileks dan menenangkan pikiran, sedangkan meditasi flow biasanya dilakukan oleh orang yang sering melakukan meditasi, hal itu terkait dengan pengalaman.

Subjek mengaku telah merasakan efek positif dari meditasi. Efek positif yang dirasakan subjek terwujud dalam perubahan perilakunya. Ia yang dahulu termasuk pribadi yang emosional, yang ketika marah akan mengajak orang lain berkelahi walau tanpa sebab, kini dapat mengontrol kemarahannya.

Subjek mengetahui apa yang harus dilakukannya ketika meditasi, yaitu tenang dan tidak berpikir macammacam. Saat meditasi, subjek meleburkan diri di dalamnya. Ia seolaholah bersatu dan menyatu dalam kesunyian meditasi. Ia tak merasakan dan melihat tubuh, tak ada orientasi arah, baik utara maupun selatan. Yang dihirupnya adalah aroma kesejukan, kedamaian, ketenangan yang bermuara pada perasaan bahagia. Hal itu sangat menyenangkan baginya. Tak hanya arah yang terlupakan, waktu pun seolah ikut mendistorsikan dirinya. Pikiran, perhatian, dan tubuhnya hanya terfokus dan terkonsentrasi penuh pada kegiatannya itu. Ia tak memikirkan hal lain di luar itu. Tujuannya hanya satu, yaitu untuk mencapai tingkat spiritual yang lebih tinggi yang pada akhirnya akan mendekatkan dirinya pada Sang 
Pencipta. Tak ada tujuan lain selain itu. Sayangnya, subjek sering terdistraksi oleh kelelahan fisiknya. Ketika fisiknya lelah, ia tak lagi merasakan flow. Untuk mengatasi distraksi tersebut, subjek mengulang aktivitasnya dari awal. Walau diakuinya hal itu tidak efektif, dalam arti pengulangan tersebut tidak dapat memanggil flow kembali-yang dalam hal ini berarti subjek gagal-, namun subjek tak memiliki kekhawatiran bahwa ia akan gagal.

Menurut subjek, meditasi membutuhkan kemampuan khusus. Kemampuan khusus tersebut adalah kemampuan untuk menurunkan gelombang otak dari beta menjadi alpha. Dikatakan subjek, walau meditasi terjadi ketika otak berada dalam gelombang alpha, tetapi meditator tetap sadar. Subjek mengatakan bahwa flow sama dengan mistism dalam dunia meditasi. Mistism berarti masuk ke alam lain yang hampa, tidak merasakan dan melihat tubuh, tidak ada utara dan selatan, serta ada suatu rasa-sensasi sejuk-yang dialami. Kesulitan dan tantangan yang dihadapinya ada dua, yaitu kelelahan fisik dan rasa kantuk yang menyerang, karena selain waktu senggang, subjek pun melakukan meditasi saat malam hari. Dalam menghadapi kesulitan dan tantangan tersebut, subjek merasa yakin dengan kemampuan yang dimilikinya, sehingga tak muncul rasa takut akan gagal. Subjek merasa puas dan bahagia setelah meditasi karena flow dalam meditasi adalah tujuan dalam meditasi.

Dalam belajar, subjek mengaku tidak pernah mengalami kondisi flow karena konsep flow yang dipahami subjek adalah konsep flow yang ia alami dalam meditasi, yang harus dalam kondisi tenang dan tutup mata. Sedangkan dalam belajar kita membutuhkan indera penglihatan yang terbuka untuk membaca, merangkum, dan lain sebagainya. Menurut subjek, hal itu sangat bertentangan. Namun, subjek mengetahui apa yang harus ia lakukan ketika belajar. Misalnya, ketika mengerjakan tugas membuat makalah tentang depresi, subjek mengetahui bahan apa saja yang harus ia cari seperti faktor penyebabnya, terjadi pada masa tua atau masa muda, akibat yang ditimbulkannya, dan hal-hal yang harus dilakukan untuk mengantisipasinya.

Dalam mengerjakan tugas, subjek merasa senang dan menikmati kegiatan itu ketika hasilnya memuaskan. Saat hasil yang diperolehnya tidak memuaskan, subjek tidak merasa senang. Kesulitan dan tantangan yang dihadapi subjek ketika mengerjakan tugas adalah dalam menyelesaikannya. Tetapi subjek menganggap tugas tersebut bukan sebagai tantangan, melainkan sebagai kewajiban yang harus diselesaikannya. Walau menganggap tugas sebagai kewajiban, subjek mengaku tidak pernah merasa bosan ketika mengerjakan tugas karena subjek termasuk orang yang statis yang tidak terlalu suka dengan perubahan. Rutinitas menurut subjek adalah hal yang biasa dan menyenangkan.

Banyaknya tugas yang harus diselesaikan membuat subjek sering merasa cemas. Subjek takut jika tugastugas tersebut tidak selesai tepat waktu atau selesai tetapi tidak optimal. Subjek mengaku bahwa ia akan masih merasa 
cemas sebelum tugas yang dikerjakannya benar-benar selesai. Walau demikian, subjek yakin bahwa tugas-tugasnya akan selesai karena hal itu merupakan satu-satunya jalan untuk tugas selesai. Dalam mengerjakan tugas, subjek termotivasi. Saat termotivasi, subjek merasakan dorongan dan energi lebih untuk mengerjakan tugas.

Distraksi pernah dialami subjek dalam mengerjakan tugas. Yang menyebabkan subjek terdistraksi adalah pecahnya konsentrasi karena kelelahan fisik yang sangat. Subjek mengaku bahwa ia terganggu dengan distraksi yang dialaminya karena hal itu menyebabkan apa yang dipelajarinya menghilang. Untuk menanggulanginya, subjek akan memulai dari awal lagi. Distraksi menurut subjek hanya disebabkan oleh fisik yang terlalu lelah. Selain itu, misalnya suara tawa anak kos, suara kendaraan yang masuk ke kos, tidak mengganggu. Diakuinya, ia adalah tipe orang yang susah untuk terganggu oleh hal-hal seperti itu.

Subjek termasuk orang yang fokus ketika belajar. Ia tidak mengalami distraksi saat belajar-kecuali hanya ketika fisiknya kelelahan-, ia menemukan banyak ide ketika mengerjakan tugas, perhatiannya hanya tertuju pada tugas dan tidak pernah ingat dengan tugas lain ketika sedang mengerjakan suatu tugas.

Subjek mengaku bahwa ia menikmati mengerjakan tugas ketika tugas tersebut manusiawi, dalam arti dalam sisi kuantitas, tidak terlalu banyak, karena jika tugas yang harus diselesaikannya banyak, ia akan merasa cemas karena tidak dapat menguasainya dan selesai dengan optimal. Rasa puas hanya dialami subjek ketika tugasnya selesai dengan optimal. Dalam mengerjakan tugas, subjek akan membuat jadwal. Ia melihat jam hanya untuk menentukan jadwal dan kemajuan dari mengerjakan tugas. Ketika tubuhnya sudah mulai lelah, ia akan berhenti mengerjakan tugas. Subjek mengaku bahwa ia masih merasakan kehadiran waktu ketika mengerjakan tugas, dalam arti ia tidak merasa bahwa seolah-olah waktu terdistorsi.

Bagi subjek, belajar adalah cara mendapat pengalaman baru. Subjek memaknai belajar sebagai cara agar ilmu dan pengalaman bertambah. Yang mendorong subjek untuk belajar adalah karena sistem yang bekerja di negara ini menghargai orang yang pintar, bukan orang yang kuat secara fisik. Jadi dengan belajar, seseorang mendapat banyak pengalaman dan kesempatan untuk bertahan hidup. Selain itu, yang membuat subjek termotivasi untuk belajar adalah untuk mencari penghasilan. Yang ingin dicapai subjek dalam belajar adalah tataran pengetahuan dan atau cara berpikir yang setingkat atau beberapa tingkat lebih tinggi dibanding orang pada umumnya.

Subjek lebih menikmati meditasi daripada kegiatan belajar karena menurut subjek, dalam belajar kita selalu terfokus akan tugas dan penyelesaiannya, dalam artian deadline, sedangkan dalam meditasi tidak ada deadline, dapat dilakukan kapan saja dan sangat rileks, sementara belajar tidak dapat membuat rileks. 


\section{Diskusi}

Csikzentmihalyi

(2008)

mendefinisikan flow sebagai suatu keadaan dimana seseorang melebur dalam suatu kegiatan yang ia senangi, dan pengalaman tersebut menimbulkan suatu kesenangan tersendiri yang membuat orang itu akan melakukannya lagi sekalipun hal itu memakan biaya, hanya untuk mengalami "sensasi rasa" yang timbul ketika melakukan kegiatan tersebut. Csikzentmihalyi (1996) mengatakan bahwa individu yang berada dalam kondisi flow selalu mengetahui apa yang yang harus dikerjakannya, dan mereka menikmati pekerjaan itu. Ketika meditasi, subjek mengetahui apa yang harus dikerjakannya, yaitu bersikap tenang dan tidak berpikir macam-macam. Dalam belajar pun demikian. Subjek mengetahu apa yang harus dilakukannya ketika mendapat suatu tugas membuat makalah, misalnya. Ia akan mencari bahan-bahan yang terkait dengan tugas tersebut. Subjek menikmati kedua kegiatan tersebut.

Umpan balik yang diperoleh dari kondisi flow biasanya berupa emosi yang positif seperti kepuasan, kenikmatan, kesenangan dan lain sebagainya, dan emosi tersebut berlangsung selama kondisi flow (Csikzentmihalyi, 1996). Pada subjek, ia merasakan emosi positif ketika meditasi, yaitu kedamaian dan ketenangan. Demikian juga dalam belajar, subjek merasakan emosi positif, yaitu rasa senang. Tetapi emosi positif yang dirasakan subjek ketika belajar hanya dirasakannya jika hasilnya memuaskan. Jika tidak memuaskan, subjek tidak merasakan senang.

Aktivitas yang dilakukan untuk mendapatkan kondisi flow harus seimbang antara kemampuan dengan kesulitan dan tantangannya, tidak terlalu mudah atau tidak terlalu sulit (Csikzentmihalyi, 1996). Pada subjek, terjadi keseimbangan antara kemampuan yang dimiliki dengan tingkat kesulitan dan tantangan yang dihadapi dalam meditasi. Kesulitan dan tantangan yang dihadapi subjek dalam meditasi ada dua, yaitu kelelahan fisik dan rasa kantuk yang menyerang. Sedangkan subjek memiliki kemampuan untuk menurunkan gelombang otak dari beta menjadi delta, dan ia tetap sadar, sehingga dalam meditasi, subjek merasa rileks. Baumann dan Scheffer (2010) menjelaskan bahwa jika kemampuan yang dimiliki individu melebihi tingkat kesulitan, ia akan merasa rileks atau kebosanan.

Sebaliknya, tidak terdapat keseimbangan antara kemampuan yang dimiliki dengan tingkat kesulitan dan tantangan yang dihadapi subjek dalam belajar. Kesulitan dan tantangan yang dihadapi subjek ketika mengerjakan tugas adalah dalam menyelesaikannya. Banyaknya tugas yang harus diselesaikan membuat subjek sering merasa cemas. Subjek takut jika tugastugas tersebut tidak selesai tepat waktu atau selesai tetapi tidak optimal. Subjek mengaku bahwa ia masih merasa cemas sebelum tugas yang dikerjakannya benar-benar selesai. Baumann dan Scheffer (2010) menjelaskan bahwa jika tingkat kesulitan melebihi kemampuan 
yang dimilikinya, ia akan merasakan sangat bersemangat untuk melakukan kegiatan itu atau ia merasakan kecemasan.

Untuk mencapai kondisi flow, individu membutuhkan fokus yang terarah serta konsentrasi penuh terhadap apa yang dikerjakan dengan batasan-batasan yang jelas (Csikzentmihalyi, 1996). Pada subjek, pikiran, perhatian, dan tubuhnya terfokus dan terkonsentrasi penuh pada meditasi. Dalam belajar, ia pun fokus. Ia menemukan banyak ide ketika mengerjakan tugas, tidak mengalami distraksi, dan perhatiannya hanya tertuju pada tugas.

Individu yang mengalami flow "memberikan" pikiran, kesadaran dirinya, dan terfokus pada kegiatan yang sedang dilakukannya saat itu juga. Mereka tidak memikirkan hal-hal lain di luar kegiatan itu (Csikzentmihalyi, 1996). Subjek tak memikirkan hal lain di luar meditasi ketika ia meditasi. Pikiran, perhatian, dan tubuhnya hanya terfokus dan terkonsentrasi penuh pada meditasi. Dalam belajar pun ia tidak pernah ingat dengan tugas lain ketika sedang mengerjakan suatu tugas.

Ketika individu mengkhawatirkan kegagalan, individu tidak akan dapat berkonsentrasi total karena perhatiannya akan terbagi antara apa yang ia lakukan dan perasaan untuk mengendalikan kegagalan itu (Csikzentmihalyi, 1996). Dalam meditasi, walau subjek memiliki kemungkinan gagal karena distraksi yang tiba-tiba menyerang, dan diakuinya pengulangan meditasi saat distraksi itu tidak efektif, subjek tak memiliki kekhawatiran bahwa ia akan gagal. Sebaliknya, dalam belajar subjek memiliki kekhawatiran. Kekhawatiran tersebut berbentuk rasa takut jika tugastugasnya tidak selesai tepat waktu atau selesai tetapi tidak optimal. Subjek mengaku bahwa ia masih merasa cemas sebelum tugas yang dikerjakannya benar-benar selesai.

Dalam kondisi flow, kesadaran individu seolah-olah "menghilang" dan dirinya masuk ke dalam suatu dunia yang diciptakan oleh kegiatan yang tengah dilakukannya tersebut (Csikzentmihalyi, 1996). Ketika meditasi, subjek benar-benar melebur di dalamnya. Kesadarannya seolah-olah menghilang dan ia menyatu dalam meditasi. Ia tak merasakan dan melihat tubuh, tak ada orientasi arah, utara maupun selatan. Yang dirasakannya adalah kesejukan, kedamaian, ketenangan yang bermuara pada perasaan puas dan bahagia. Sedangkan dalam belajar, subjek masih merasakan kesadaran dirinya. Ia tidak melebur dalam tugas itu. Subjek mengaku bahwa ia menikmati mengerjakan tugas ketika tugas tersebut manusiawi, dalam arti dari sisi kuantitas, tugas tersebut tidak terlalu banyak. Rasa puas hanya dialami subjek ketika tugasnya selesai dengan optimal.

Ketika berada dalam kondisi flow, individu melupakan waktu. Jam yang terlewati berjalan seperti menit. Seberapa banyak waktu yang terlewati tergantung pada apa yang individu lakukan (Csikzentmihalyi, 1996). Waktu seolah terlupakan ketika subjek melakukan meditasi. Tetapi dalam belajar, subjek masih dapat merasakan 
kehadiran waktu, dalam arti ia tidak merasa bahwa seolah-olah waktu terdistorsi.

Dalam kondisi flow, kegiatan yang dilakukan individu berubah menjadi autotelik. Autotelik berarti ketika individu melakukan suatu kegiatan, ia melakukan itu bukan karena mengharapkan beberapa keuntungan, melainkan karena "sensasi rasa" yang ditimbulkan kegiatan itulah yang membuatnya menjadi istimewa. Ketika mengalami autotelik, individu memberikan perhatiannya demi kegiatan itu sendiri (Csikzentmihalyi, 2008). Tidak ada alasan lain untuk melakukan kegiatan itu kecuali untuk merasakan pengalaman yang diberikan (Csikzentmihalyi, 1996). Yang mendorong subjek untuk melakukan meditasi adalah keinginannya untuk mencapai tingkat spiritual yang lebih tinggi yang pada akhirnya akan mendekatkan dirinya pada Sang Pencipta. Selain itu, subjek mengaku tak memiliki motivasi lain. Sedangkan yang mendorong subjek untuk belajar adalah karena sistem yang bekerja di negara ini menghargai orang yang pintar, bukan orang yang kuat secara fisik. Jadi dengan belajar, seseorang mendapat banyak pengalaman dan kesempatan untuk bertahan hidup. Selain itu, motivasi subjek dalam belajar adalah untuk mencari penghasilan. Csikzentmihalyi (2008) mengatakan bahwa kegiatan yang dilakukan seseorang karena alasan eksternal dinamakan exotelic. Dengan demikian, dalam meditasi subjek menjadi autotelik, sedangkan dalam belajar subjek menjadi eksotelik.
Dari pembahasan di atas, dapat disimpulkan bahwa subjek mempunyai ke sembilan komponen flow ketika ia melakukan meditasi, sedangkan subjek hanya memiliki tiga komponen flow ketika ia dalam kondisi belajar. Dengan demikian, flow yang dialami subjek sebagai mahasiswa adalah bukan dalam hal belajar, melainkan dalam hal lain, yaitu meditasi. Yang menyebabkan subjek tidak mengalami flow dalam belajar adalah karena menurut subjek, belajar dipenuhi oleh tekanan tugas dan batas akhir pengumpulan tugas, sedangkan meditasi tidak dibatasi waktu. Meditasi dapat dilakukan kapan saja. Selain itu, meditasi membuat subjek rileks. Hal yang sama tidak terjadi ketika belajar.

Pendapat subjek bahwa belajar tidak membuat rileks karena dipenuhi oleh tekanan tugas dan batas akhir pengumpulan tugas merupakan persepsi subjek tentang belajar. Persepsi adalah cara pandang individu terhadap sesuatu, yang terbentuk dari pengalaman dan atau pikiran. Pada penelitian ini, dikarenakan subjek mempersepsi bahwa belajar penuh dengan tekanan dan tidak membuat rileks, maka subjek tidak mengalami flow dalam belajar. Dikarenakan subjek tidak mengalami flow dalam belajar, maka efek flow dalam belajar tidak ditemukan pada diri subjek.

\section{Kesimpulan}

Penelitian ini menemukan bahwa flow yang dialami ketika meditasi tidak serta merta dialami ketika belajar. Salah satu penyebabnya adalah persepsi bahwa belajar dipenuhi dengan tekanan 
dan tidak membuat rileks. Dengan demikian, bagi peneliti selanjutnya yang ingin meneliti lebih jauh tentang flow dalam belajar dapat menambahkan variabel persepsi mengenai belajar. Peneliti lain juga dapat menggunakan pendekatan kuantitatif agar dapat mencapai hasil yang lebih komprehensif.

\section{Kepustakaan}

Baumann, N., Scheffer, D. (2010). Seeking Flow in the Achievement Domain: The Achievement Flow Motive behind Flow Experience. Journal Motivation Emotion: 1-18

Bassi, M., Steca, P., Delle Fave, A., Caprara, G.V. (2007). Academic SelfEfficacy Belief and Quality of Experience in Learning. Journal Youth Adolescence 32: 301-312

Boeree, C. (2009). Personality Theories: Melacak Kepribadian Anda bersama Psikolog Dunia. Yogyakarta, PrismaSophie

Csikzentmihalyi, M. (1996). Creativity: Flow and The Psychology of Discovery and Invention. New York: HarperCollins (2008). Flow: The Psychology of Optimal Experience. HarperCollins e-books (1997). Happiness and Creativity: Going with the Flow. Academic Research Library: 31: 5: 8-12 Chaplin, J.P. (2002). Kamus Lengkap Psikologi. Jakarta: Rajawali Pers

Egbert, J. (2003). A Study of Flow Theory in the Foreign Language Classroom. The Modern Language Journal: 87: 4: 499-518
Esenger, S., Rheinberg, F. (2008). Flow, Performance and Moderators of Challenge-Skill Balance. Journal Motivation Emotion 32: 158-172

Hartley, J. (1999). Learning and Studying: A Research Perspective. New York: Routledge

Herdiansyah, H. (2010). Metodologi Penelitian Kualitatif untuk Ilmu-Ilmu Sosial. Jakarta: Salemba Humanika . (2007). Kecemasan dan Strategi Coping Wanita dan Waria Pelacur. Tesis. Yogyakarta: Universitas Gadjah Mada (tidak diterbitkan)

Hergenhahn, B.R., Olson, M.H. (2008). Theories of Learning. Jakarta: Kencana Prenada Media Group

Kertamuda, F. (2006). Psikologi Belajar: Diktat Pengajaran Mata Kuliah Psikologi Belajar. Jakarta: Universitas Paramadina (tidak diterbitkan)

Martin, A.J., Jackson, S.A. (2008). Brief Approach to Assessing Task Absorption and Enhancedd Subjective Experience: Examining 'Short' and 'Core' Flow in Diverse Performance Domains. Journal Motivation Emotion 32: 141-157

Miles, M. B \& Huberman, A. M. (1994). Qualitative Data Analysis: An Expanded Sourcebook. Thousand Oaks: Sage Publication

Nakamura, J., Csikzentmihalyi, M. (2002). The Concept of Flow. In Handbook of Positive Psychology. Snyder, C.R., Lopez, S.J. (ed). New York: Oxford University Press

Papalia, D.E., Olds, S.W., Feldman, R.D. (2005). Human Development. New York: McGraw Hill 
Poerwandari, E.K. (1998). Pendekatan Kualitatif dalam Penelitian Psikologi. Jakarta: Lembaga Pengembangan Sarana Pengukuran dan Pendidikan Psikologi (LPSP3) Fakultas Psikologi Universitas Indonesia . (2005). Pendekatan Kualitatif untuk Penelitian Perilaku Manusia. Jakarta: Lembaga Pengembangan Sarana Pengukuran dan Pendidikan Psikologi (LPSP3) Fakultas Psikologi Universitas Indonesia

Santrock, J.W. (2002). Life Span Development: Perkembangan Masa Hidup. Jakarta: Erlangga
Schouten, J.W., McAlexander, J.H., Koenig, H.F. (2007). Transcendent Customer Experience and Brand Community. Journal of the Academic Marketing Science 35: 357-368

Scoureby, J., Shelton, B.E. (2010). Visual Perspectives within Educational Computer Games: Effects on Presence and Flow within Virtual Immersive Learning Environment. Journal of Instr Science: 1-28

Slavin, R.E. (2008). Psikologi Pendidikan: Teori dan Praktik. Jakarta: PT Indeks

Stewart, C. J \& Cash, W. B. 2006. Interviewing: Principles and Practices. New York: McGraw- Hill

Waterman, A.S. (2005). When Effort Is Enjoyed: Two Studies of Intrinsic Motivation for Personally Salient Activities. Journal Motivation and Emotion 29: 3: 165-188 